\title{
Influence of the Presence of Choline Chloride on the Classical Mechanism of "Gelatinization" of Starch
}

\author{
Doina Crucean 1,2,3, Bruno Pontoire 2,3, Gervaise Debucquet ${ }^{4}$, Alain Le-Bail 1,3 and Patricia Le-Bail ${ }^{2,3, *}$ \\ 1 ONIRIS, UMR 6144 GEPEA CNRS, F-44322 Nantes, France; doina.crucean@oniris-nantes.fr (D.C.); \\ alain.lebail@oniris-nantes.fr (A.L.-B.) \\ 2 INRAe, UR1268 Biopolymers Interactions Assemblies, BP 71627, F-44316 Nantes, France; \\ bruno.pontoire@inrae.fr \\ 3 SFR IBSM 4202, BP 71627, F-44316 Nantes, France \\ 4 Audencia Business School, Human and Social Sciences, 8 Route de la Jonelière, BP 31222, \\ F-44312 Nantes, France; gdebucquet@audencia.com \\ * Correspondence: patricia.le-bail@inrae.fr
}

check for updates

Citation: Crucean, D.; Pontoire, B.; Debucquet, G.; Le-Bail, A.; Le-Bail, P. Influence of the Presence of Choline Chloride on the Classical Mechanism of "Gelatinization" of Starch. Polymers 2021, 13, 1509. https:// doi.org/10.3390/polym13091509

Academic Editors: Rafael

Antonio Balart Gimeno, Daniel

García García, Vicent

Fombuena Borrás, Luís Jesús Quiles Carrillo and Marina Patricia Arrieta Dillon

Received: 21 March 2021

Accepted: 28 April 2021

Published: 7 May 2021

Publisher's Note: MDPI stays neutral with regard to jurisdictional claims in published maps and institutional affiliations.

Copyright: (c) 2021 by the authors. Licensee MDPI, Basel, Switzerland. This article is an open access article distributed under the terms and conditions of the Creative Commons Attribution (CC BY) license (https:/ / creativecommons.org/licenses/by/ $4.0 /)$.

\begin{abstract}
The aim of this research is to contribute to a better understanding the destructuration of three native starches and a wheat flour in mixtures of water and choline chloride. Model systems have thus been defined to allow a better approach to hydrothermic transformations related to the interactions between choline chloride and starch. We have observed that choline chloride has an impact on the gelatinization of starch which corresponds to the stabilizing salts phenomenon. The depolymerization and dissolution of the starch have also been demonstrated and can there dominate the gelatinization. However, the results obtained in X-ray diffraction by heating cell have shown that the exotherm which appeared was not only related to the depolymerization of the starch, but that a stage of crystalline rearrangement of the starch coexisted with this phenomenon.
\end{abstract}

Keywords: allotropic transition; choline chloride; plasticizer; starch dissolution

\section{Introduction}

Choline chloride, because of its unique nutrient functionality and its ability to enhance flavor, provides a new option as a partial substitute for sodium chloride in reformulations of processed foods to reduce their sodium content. To date, very few studies have explored the potential of choline chloride to act as a substitute for salt. Locke and Fielding were the first to identify the properties of choline chloride to improve the salty taste of food products [1-3].

Starch is a natural polymer with particular properties unlike those of traditional polymers. As a heterogeneous material, it has macromolecular structures bound in a granular superstructure.

When native starch granules are heated in water (excess of water conditions, around $60 \%$ water $\mathrm{wb}$ ), their semicrystalline nature and three-dimensional architecture are gradually disrupted, resulting in a phase transition from the ordered granular structure to a disordered state in water, which is known as "gelatinization" [4,5]. Gelatinization is an irreversible process that includes several steps, such as granule swelling, native crystalline melting (loss of birefringence), and leaching of fractions of polymers or of polymers in particular amylose chains resulting in a molecular solubilization [6]. The gelatinization process is essential in the processing of foods. For improving the properties of starch and adding new functionalities, it is common to carry out the hydrothermal transformation of starch in environments containing substances other than water. Various plasticizers and additives for starch processing have been used, including polyols (glycerol, glycol, sorbitol, etc.) and nitrogen-containing compounds (urea, ammonium derived, and amines) [7,8]. An alternative class of materials known as ionic liquids, now commonly defined as salts, that 
melt below $100{ }^{\circ} \mathrm{C}$ has recently attracted much interest for the processing of biopolymers such as starch.

Choline chloride solubilized in water gives an ionic liquid. Several studies have shown the effects of ionic liquids (solvents and plasticizers) based on the effects of choline chloride on starch [9-14]. A study conducted by Decaen et al. highlights the plasticization of starch by ionic liquids based on an examination of choline [15]. The destructuration of native maize starch in mixtures of water and ionic liquids containing choline cations was studied in dynamic heating conditions, combining calorimetry, rheology, microscopy, and chromatographic techniques by Sciarini et al. [16].

This work presents the mechanism of choline chloride penetration into the starch grain and its impact on gelatinization and the structural evolution of starch during heating kinetics.

\section{Materials and Methods}

\subsection{Materials}

Wheat flour (type 65) was supplied by Evelia, La Varenne, France. Wheat starch was purchased from Loryma GmbH (Zwingenberg, Germany), and waxy corn starch was purchased from Roquette Italia SpA (Cassano Spinola, Italy). Potato starch and choline chloride $\left(\mathrm{C}_{5} \mathrm{H}_{14} \mathrm{ClNO}\right)$ were supplied by Sigma-Aldrich (France).

\subsection{Sample Preparations}

The measurements were carried out on wheat flour $\left(\mathrm{F}_{\mathrm{w}}\right)$ and wheat, potato, and waxy corn starch $\left(\mathrm{S}_{\mathrm{w}}, \mathrm{S}_{\mathrm{p}}\right.$, and $\mathrm{S}_{\mathrm{wc}}$, respectively) solubilized in an aqueous solution containing different concentrations of choline chloride.

The model systems studied being composed of three ingredients (flour, chlorine choline, and water) and were presented under the form of Equation (1) with $\mathrm{F}_{\mathrm{x}}, \mathrm{Cc}_{\mathrm{y}}$, and $\mathrm{W}_{\mathrm{Z}}$ being the flour (or starch), choline chloride, and water content, respectively.

$$
\mathrm{F}_{\mathrm{x}} \mathrm{Cc}_{\mathrm{y}} \mathrm{W}_{\mathrm{z}}
$$

A mixing design has been used (1). The factors are the concentrations of each component of the mixture. Responses are expressed as a function of these concentrations with the sum of the mass fraction of each component being equal to $100(x+y+z=100)$. For each analysis, $5 \mathrm{~g}$ of mixture was prepared.

The mode of preparation (quoted ILS = "Ionic Liquid + Starch" for the rest of the paper) consisted in adding the choline chloride under the form of ionic liquid [15] (previous dissolution of $\mathrm{Cc}$ and water for one hour before starting the experiments); in that case, the script that was used was " $(\mathrm{C} c+\mathrm{W})$ ", and the ionic liquid was then added to the flour. These systems were written with the following script: $F_{x}\left[C_{y} W_{z}\right]$.

All analyses were repeated in triplicate. A statistical analysis was performed with variance analysis $(p<0.005)$ to detect significant differences.

\subsection{Methods}

\subsubsection{Differential Scanning Calorimetry Measurements}

Samples weighing $500 \mathrm{mg}$ were placed in stainless steel pans, and a reference cell was prepared by adding an amount of water equal to the volume of water in the sample cells. The cells were then sealed with a heat-resistant seal. The cell containing the sample was agitated (50 rpm at room temperature) for one hour and then placed in the oven of the appliance. The pans were heated at a rate of $1{ }^{\circ} \mathrm{C} / \mathrm{min}$ from 10 to $120^{\circ} \mathrm{C}$ by using the SETARAM microcalorimeter ( $\mu$ DSC) III (France). Scans were run on the following starch suspensions: $\mathrm{S}_{\mathrm{P} 20}\left[\mathrm{Cc}_{\mathrm{x}} \mathrm{W}_{\mathrm{y}}\right], \mathrm{S}_{\mathrm{W} 20}\left[\mathrm{Cc}_{\mathrm{x}} \mathrm{W}_{\mathrm{y}}\right], \mathrm{S}_{\mathrm{WC} 20}\left[\mathrm{Cc}_{\mathrm{x}} \mathrm{W}_{\mathrm{y}}\right]$, and $\mathrm{F}_{\mathrm{W} 20}\left[\mathrm{Cc}_{\mathrm{x}} \mathrm{W}_{\mathrm{y}}\right]$. All measurements were made at least in triplicate.

Thermal transitions were defined as $\mathrm{T}_{\mathrm{Ge}}$ (peak temperature gelatinization), and $\Delta \mathrm{H}_{\mathrm{Ge}}$ denotes the transition enthalpies for different endotherms. The enthalpies were determined 
by endotherm integration, and all traces were normalized to $1 \mathrm{mg}$ of dried sample. The partial enthalpies were calculated from the onset of the endotherm to the end (every $1^{\circ} \mathrm{C}$ ).

\subsubsection{X-ray Diffraction}

The samples containing flour and starch suspended in $\left[\mathrm{C}_{56} \mathrm{~W}_{24}\right]$ were prepared as follows: $\mathrm{S}_{\mathrm{WC} 20}\left[\mathrm{Cc}_{56} \mathrm{~W}_{24}\right], \mathrm{S}_{\mathrm{P} 20}\left[\mathrm{C}_{56} \mathrm{~W}_{24}\right], \mathrm{S}_{\mathrm{W} 20}\left[\mathrm{CC}_{56} \mathrm{~W}_{24}\right]$, and $\mathrm{F}_{\mathrm{W} 20}\left[\mathrm{C}_{56} \mathrm{~W}_{24}\right]$. The appropriate amounts of choline chloride, water (when required), and starch were weighed. The same formulations without choline chloride were studied: $\mathrm{S}_{\mathrm{WC} 45} \mathrm{~W}_{55}, \mathrm{~S}_{\mathrm{P} 45} \mathrm{~W}_{55}, \mathrm{~S}_{\mathrm{W} 45} \mathrm{~W}_{55}$, and $\mathrm{F}_{\mathrm{W} 45} \mathrm{~W}_{55}$, corresponding to the same $\mathrm{F} / \mathrm{W}$ ratio as the previous mixtures.

The samples were examined by wide-angle (WAX) X-ray diffraction. The measurements were performed using a D8 Discover spectrometer from Bruker-AXS (Karlsruhe, Germany). $\mathrm{Cu} \mathrm{K} \alpha_{1}$ radiation, produced in a sealed tube at $40 \mathrm{kV}$ and $40 \mathrm{~mA}$, was selected and parallelized using a double Gobël mirror parallel optics system and collimated to produce a $500 \mu \mathrm{m}$ beam diameter with sample alignment by a microscopic video and laser. The data were monitored by a VANTEC 500 2D detector (Bruker, Karlsruhe, Germany) for $10 \mathrm{~min}$ and normalized.

The sample was placed in a capillary with a diameter of $1.5 \mathrm{~mm}$, and a second capillary was introduced into the first to avoid loss of water during the rise in temperature; the two capillaries were sealed. The as-prepared capillary was placed in a heating stage HFS91 (Linkam, Tadworth, UK). The detector was positioned at a focusing distance of $8.6 \mathrm{~cm}$ from the sample surface. It was in direct beam position [17]. The heating kinetic applied to the sample was $1{ }^{\circ} \mathrm{C} / \mathrm{min}$ from 20 to $120^{\circ} \mathrm{C}$. Every $10^{\circ} \mathrm{C}$, a plateau of 10 min was introduced to enable the acquisition of the diffraction spectrum.

\section{Results and Discussion}

\subsection{Gelatinization of Different Starches}

The thermograms of wheat flour $\left(\mathrm{F}_{\mathrm{W}}\right)$, wheat starch $\left(\mathrm{S}_{\mathrm{W}}\right)$, potato starch $\left(\mathrm{S}_{\mathrm{P}}\right)$, and waxy-corn starch $\left(\mathrm{S}_{\mathrm{WC}}\right)$ in excess water $(\mathrm{W}=80 \%)$ should serve as a reference and allow comparison with the $\mathrm{F}_{20}\left[\mathrm{C}_{\mathrm{x}} \mathrm{W}_{\mathrm{y}}\right]$ systems, i.e., when choline chloride is added to the aqueous phase. All the samples exhibited an endotherm on their thermograms, which corresponded to the gelatinization of the starch at the following temperatures: $\mathrm{F}_{\mathrm{W}} 61.7 \pm 0.2{ }^{\circ} \mathrm{C}$, $\mathrm{S}_{\mathrm{W}} 58.1 \pm 0.1{ }^{\circ} \mathrm{C}, \mathrm{S}_{\mathrm{WC}} 70.8 \pm 0.1^{\circ} \mathrm{C}$, and $\mathrm{S}_{\mathrm{P}} 65.7 \pm 0.1^{\circ} \mathrm{C}$ (Table 1). The gelatinization temperatures of the different samples studied increased in the following order: $\mathrm{T}_{\mathrm{Ge}}\left(\mathrm{S}_{\mathrm{W}}\right)$ $<\mathrm{T}_{\mathrm{Ge}}\left(\mathrm{F}_{\mathrm{W}}\right)<\mathrm{T}_{\mathrm{Ge}}\left(\mathrm{S}_{\mathrm{P}}\right)<\mathrm{T}_{\mathrm{Ge}}\left(\mathrm{S}_{\mathrm{WC}}\right)$, whereas the gelatinization enthalpies increased in the following order: $\Delta \mathrm{H}_{\mathrm{Ge}}\left(\mathrm{F}_{\mathrm{W}}\right)<\Delta \mathrm{H}_{\mathrm{Ge}}\left(\mathrm{S}_{\mathrm{W}}\right)<\Delta \mathrm{H}_{\mathrm{Ge}}\left(\mathrm{S}_{\mathrm{WC}}\right)<\Delta \mathrm{H}_{\mathrm{Ge}}\left(\mathrm{S}_{\mathrm{P}}\right)$.

Table 1. Enthalpies $\left(\Delta \mathrm{HGe}, \mathrm{J} / \mathrm{g}\right.$ ) and gelatinization temperatures $\left(\mathrm{TGe},{ }^{\circ} \mathrm{C}\right)$ of different flour/starch and plasticizer model systems. Enthalpies were calculated on flour or starch total dry basis.

\begin{tabular}{|c|c|c|c|c|c|c|c|c|}
\hline \multirow[t]{2}{*}{$x, y$} & \multicolumn{2}{|c|}{$\begin{array}{c}\text { Waxy-Corn Starch } \\
\mathrm{S}_{\mathrm{WC2}}\left[\mathrm{Cc}_{\mathrm{x}} \mathrm{W}_{\mathrm{y}}\right]\end{array}$} & \multicolumn{2}{|c|}{$\begin{array}{l}\text { Potato Starch } \\
S_{P 20}\left[C_{c_{x}} W_{y}\right]\end{array}$} & \multicolumn{2}{|c|}{$\begin{array}{l}\text { Wheat Starch } \\
S_{\mathrm{W} 20}\left[\mathrm{Cc}_{\mathrm{x}} \mathrm{W}_{\mathrm{y}}\right]\end{array}$} & \multicolumn{2}{|c|}{$\begin{array}{l}\text { Wheat Flour } \\
\mathrm{F}_{\mathrm{W} 20}\left[\mathrm{Cc}_{\mathrm{x}} \mathrm{W}_{\mathrm{y}}\right]\end{array}$} \\
\hline & $\Delta \mathrm{H}_{\mathrm{Ge}}, \mathrm{J} / \mathrm{g}$ & $\mathrm{T}_{\mathrm{Ge}},{ }^{\circ} \mathrm{C}$ & $\Delta \mathrm{H}_{\mathrm{Ge}}, \mathrm{J} / \mathrm{g}$ & $\mathrm{T}_{\mathrm{Ge}},{ }^{\circ} \mathrm{C}$ & $\Delta \mathrm{H}_{\mathrm{Ge}}, \mathrm{J} / \mathrm{g}$ & $\mathrm{T}_{\mathrm{Ge},}{ }^{\circ} \mathrm{C}$ & $\Delta \mathrm{H}_{\mathrm{Ge}}, \mathrm{J} / \mathrm{g}$ & $\mathrm{T}_{\mathrm{Ge},}{ }^{\circ} \mathrm{C}$ \\
\hline$x=0 y=80$ & $10.8 \pm 0.2$ & $70.8 \pm 0.1$ & $12.0 \pm 0.1$ & $65.6 \pm 0.1$ & $7.2 \pm 0.1$ & $58.1 \pm 0.1$ & $5.2 \pm 0.1$ & $61.7 \pm 0.2$ \\
\hline$x=8 y=72$ & $12.4 \pm 0.1$ & $82.9 \pm 0.1$ & $12.2 \pm 0.3$ & $71.4 \pm 0.1$ & $8.4 \pm 0.4$ & $71.0 \pm 0.1$ & $6.3 \pm 0.3$ & $73.4 \pm 0.4$ \\
\hline$x=16 y=64$ & $13.3 \pm 0.1$ & $90.1 \pm 0.2$ & $12.8 \pm 0.1$ & $77.2 \pm 0.1$ & $8.8 \pm 0.9$ & $78.6 \pm 0.1$ & $6.7 \pm 0.6$ & $80.8 \pm 0.3$ \\
\hline$x=24 y=56$ & $14.9 \pm 0.4$ & $96.1 \pm 0.2$ & $13.4 \pm 0.4$ & $84.2 \pm 0.1$ & $10.3 \pm 0.2$ & $85.2 \pm 0.1$ & $7.7 \pm 0.6$ & $86.8 \pm 0.7$ \\
\hline$x=32 y=48$ & $14.9 \pm 0.3$ & $100.0 \pm 0.1$ & $13.6 \pm 0.1$ & $91.7 \pm 0.1$ & $11.4 \pm 0.5$ & $89.9 \pm 0.1$ & $8.6 \pm 0.2$ & $91.9 \pm 0.2$ \\
\hline$x=40 y=40$ & $14.9 \pm 0.3$ & $101.3 \pm 0.1$ & $14.2 \pm 0.1$ & $99.1 \pm 0.1$ & $12.2 \pm 0.3$ & $92.7 \pm 0.1$ & $9.2 \pm 0.9$ & $94.8 \pm 0.1$ \\
\hline$x=48 y=32$ & $16.8 \pm 0.5$ & $98.6 \pm 0.1$ & $14.0 \pm 0.2$ & $104.5 \pm 0.1$ & $13.0 \pm 0.2$ & $92.2 \pm 0.1$ & $9.7 \pm 0.2$ & $93.8 \pm 0.1$ \\
\hline$x=56 y=24$ & $16.1 \pm 0.1$ & $90.7 \pm 0.1$ & $13.5 \pm 0.3$ & $102.1 \pm 0.1$ & $12.0 \pm 0.2$ & $87.1 \pm 0.3$ & $9.2 \pm 0.6$ & $87.4 \pm 0.2$ \\
\hline$x=64 y=16$ & $\mathrm{~N} / \mathrm{A}$ & $79.9 \pm 0.2$ & $\mathrm{~N} / \mathrm{A}$ & $95.5 \pm 0.2$ & $\mathrm{~N} / \mathrm{A}$ & $81.0 \pm 0.6$ & $\mathrm{~N} / \mathrm{A}$ & $84.5 \pm 0.5$ \\
\hline
\end{tabular}


The thermograms of the $\mathrm{F}_{\mathrm{W}}$ and $\mathrm{S}_{\mathrm{W}}$ samples showed a second endotherm characterized by the fusion of the amylose-endogenous lipid complexes formed during gelatinization $[18,19]$. The melting temperatures of the amylose-lipid complexes for $S_{W}$ and $F_{W}$ were $97 \pm 1{ }^{\circ} \mathrm{C}$ and $92.3 \pm 0.2^{\circ} \mathrm{C}$, respectively.

\subsection{Influence of Choline Chloride on Starch Destructuration}

Since choline chloride behaves as an ionic liquid when it is in the presence of water, its behavior during the heating of a starch granule suspension may strongly influence gelatinization. A study comparing the previously discussed aqueous-phase suspensions containing solubilized choline chloride was carried out.

Micro-DSC was used to study the physicochemical characteristics of the following suspensions: $\mathrm{S}_{\mathrm{WC} 20}\left[\mathrm{Cc}_{\mathrm{x}} \mathrm{W}_{\mathrm{y}}\right], \mathrm{S}_{\mathrm{P} 20}\left[\mathrm{Cc}_{\mathrm{x}} \mathrm{W}_{\mathrm{y}}\right], \mathrm{S}_{\mathrm{W} 20}\left[\mathrm{Cc}_{\mathrm{x}} \mathrm{W}_{\mathrm{y}}\right]$, and $\mathrm{F}_{\mathrm{W} 20}\left[\mathrm{Cc}_{\mathrm{x}} \mathrm{W}_{\mathrm{y}}\right]$.

The thermograms of the suspensions are shown in Figure 1, and their enthalpies $\Delta \mathrm{H}_{\mathrm{Ge}}$ and gelatinization temperatures $\mathrm{T}_{\mathrm{Ge}}$ are shown in Table 1 .

a

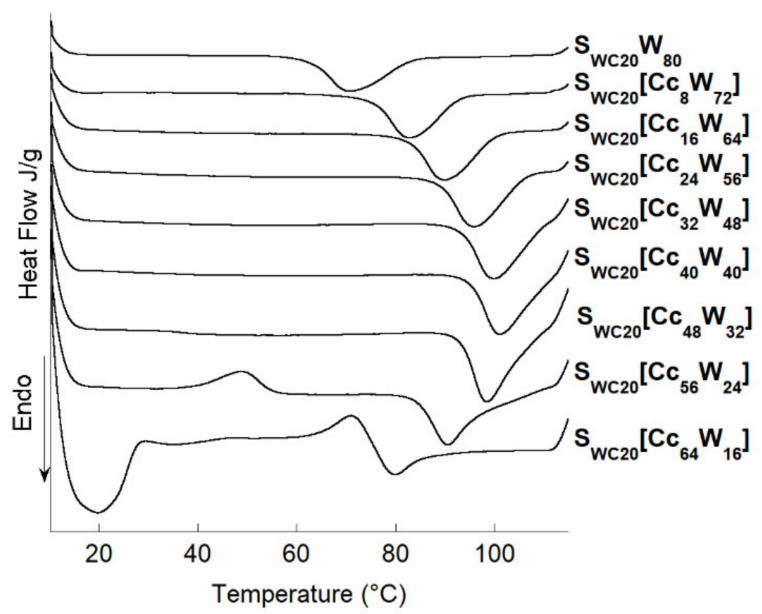

C

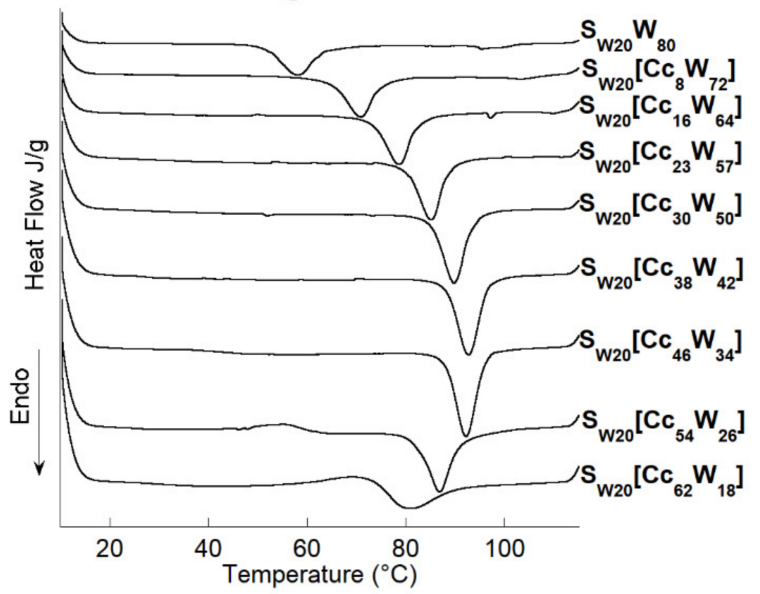

b

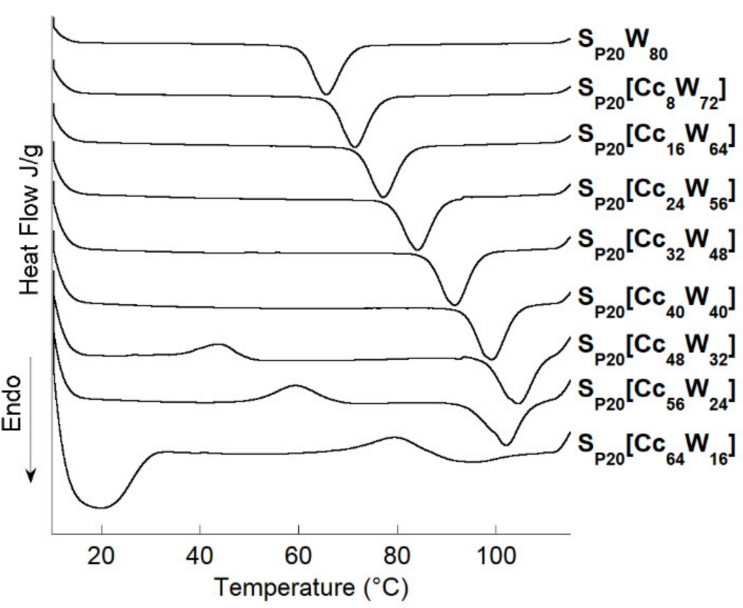

d

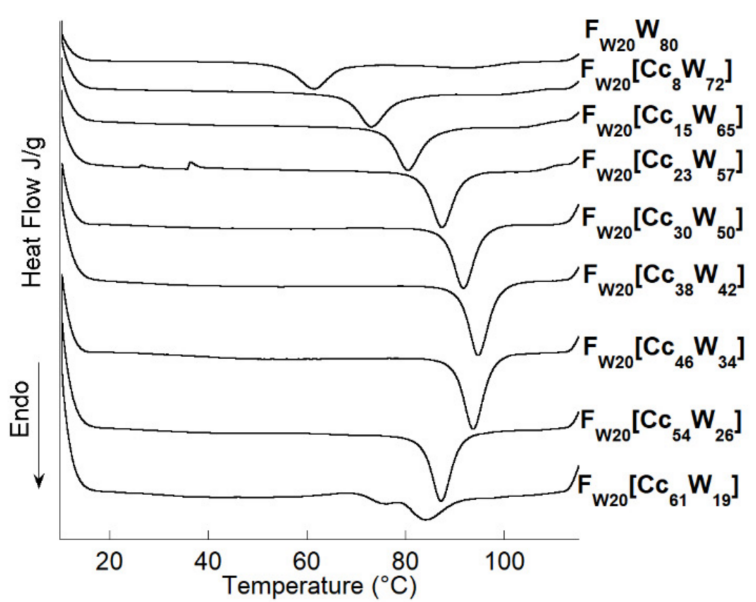

Figure 1. $\mu \mathrm{DSC}$ heating curves, $10-120^{\circ} \mathrm{C}$ at $1{ }^{\circ} \mathrm{C} / \mathrm{min}$, of: (a) waxy-corn starch, (b) potato starch, (c) wheat starch, and (d) flour at different water and chlorine chloride contents. 
At low concentrations of $\mathrm{C} c$, the starch undergoes a typical gelatinization, represented by an endothermic transition. At the same concentration, the endothermic transition attributed to the fusion of endogenous amylose-lipid complexes is also observed for $F_{W}$ and $S_{W}$. When the concentration of $C_{c}$ increases from 0 to $40 \%$ for $S_{W C}, S_{W}$, and $F_{W}$ and from 0 to $48 \%$ for $S_{P}$, the peak of gelatinization moves to a higher temperature and then decreases for all three starches and flour. The observed gelatinization temperature is always higher than that observed in pure water. However, beyond $40 \%$ for $\mathrm{S}_{\mathrm{WC}}, \mathrm{S}_{\mathrm{P}}$, and $\mathrm{F}_{\mathrm{W}}$ and beyond $48 \%$ for $\mathrm{S}_{\mathrm{W}}$, the gelatinization of the starch decreases with an increase in the B4 concentration. The same trend is observed for the enthalpies of gelatinization.

The increase in gelatinization temperature caused by $\mathrm{Cc}_{\mathrm{c}}$ and the subsequent decrease with an increasing Cc level agree with the results of Chiotelli et al. for wheat and potato starches, Chungcharoen and Lund for rice starch, Jane for corn starch, and those of Ahmad and William and Ghani et al. for sargo starch [20-24].

The shift of the gelatinization temperature toward higher temperatures as well as the increase in the total enthalpy of gelatinization in the presence of Cc may be due to the reduction of the water activity in the starch/plasticizer solution, which causes an increase in the energy required for chemical and physical reactions involving water [25] Jane [22] claimed that the effect of salts on starch gelatinization follows the "Hofmeister" series, the increase in the gelatinization temperature follows the charge density order of the ions $(\mathrm{LiCl}>\mathrm{NaCl}>\mathrm{KCl}>\mathrm{RbCl})$, that is, the order of the "structure making" effect. However, at concentrations greater than $4 \mathrm{M}$, these salts decrease the onset temperature of gelatinization. Choline reacts as an "ion structure maker".

For high Cc concentrations, exothermic transitions were observed. The exotherms started at higher temperatures as the water content decreased, and the corresponding heat released $(\Delta \mathrm{H})$ increased as well. There was a critical concentration, which depends on the type of starch used, for which both exothermic and endothermic transitions took place. For this concentration, both phenomena seem to happen at very close temperatures, at which they overlapped, resulting in a neutralization with no visible thermal effect. The same behavior was found by Sciarini et al. and Mateyawa et al. working with choline acetate and EMIMAc and by Koganti et al. using N-methyl morpholine N-oxide (NMMO) [12,16,26]. These authors attributed the exothermic transition to starch dissolution in these solvents. For low water contents $(16 \%)$, the thermograms of $\mathrm{S}_{\mathrm{P}}$ and $\mathrm{S}_{\mathrm{WC}}$ show wide endotherms at low temperatures $\left(19.7^{\circ} \mathrm{C}\right)$. This phenomenon was not visible for $S_{W}$ and $F_{W}$. A DSC study was then carried out on the $\mathrm{S}_{\mathrm{WC} 20}\left[\mathrm{Cc}_{\mathrm{x}} \mathrm{W}_{\mathrm{y}}\right]$ systems (with $\mathrm{x}$ included between 56 and 70 and y between 24 and 10) to understand this phenomenon (Figure 2).

The thermogram of pure Cc (data not shown) shows an endotherm near $73.6 \pm 0.1^{\circ} \mathrm{C}$. With the addition of water, this endotherm moves to lower temperatures and undergoes a strong shift from the baseline until disappearing. In the presence of waxy maize starch $(20 \%)$, the concentration of Cc was increased in steps of $1 \%$ (from 56 to $70 \%$ ), and water was decreased likewise (from 24 to 10\%), which produced an endotherm at low temperatures for the sample with $17 \%$ water.

During these investigations, the Cc was solubilized in water to form the plasticizer, and then the starch was added to the plasticizer. When the amount of water was sufficient, complete solubilization of the $\mathrm{Cc}$ was achieved. When the water concentration was less than $17 \%$, the solubilization of $\mathrm{C} c$ was partial, and we observed a solubilization endotherm that broadened with a decrease in the water content. For the $14 \%$ water sample, there was enough unsolubilized choline chloride for the allotropic change in choline chloride at $68^{\circ} \mathrm{C}$ to be observed.

It was assumed that the solution (water $+\mathrm{Cc}$ ) became more viscous with increasing Cc concentrations, resulting in more difficulty for the Cc solution to penetrate inside the starch granule; in turn, a shift to higher gelatinization temperatures was observed. 


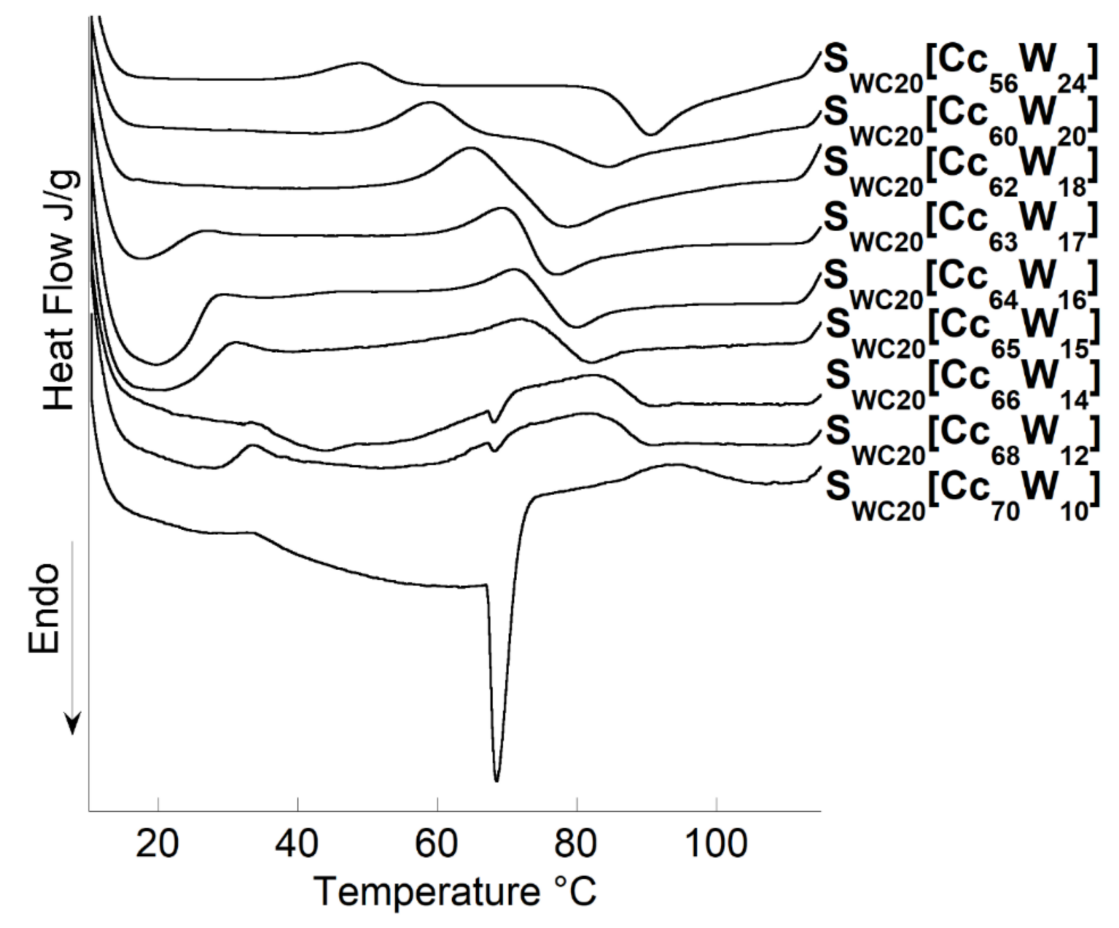

Figure 2. Microcalorimeter heating curves, $10-120^{\circ} \mathrm{C}$ at $1^{\circ} \mathrm{C} / \mathrm{min}$, of waxy-corn starch at different water, and choline chloride contents.

The effect of chlorine choline (Cc) on the gelatinization of starch is very different from that of $\mathrm{NaCl}$ observed in the literature. Indeed, if the gelatinization temperature follows the same trend when adding $\mathrm{Cc}$ or $\mathrm{NaCl}$, the enthalpy of gelatinization shows the opposite behavior. The decrease in the total enthalpy of starch gelatinization at high $\mathrm{NaCl}$ concentrations suggests a destabilization of the ordered regions of the starch in the presence of $\mathrm{NaCl}$. As explained by Chiotelli et al., sodium chloride may be hindered by polymer-polymer interactions in favor of water-polymer interactions, resulting in a lower enthalpy for fusion of organized regions. The addition of Cc causes a reorganization of the internal structure of the starch grain [20].

\subsection{Penetration of the Plasticizer into the Starch Grain}

To understand the penetration kinetics of the ionic liquid ( $\mathrm{Cc}+$ water) in the starch granule, the cumulative enthalpy curves were calculated and reported as a function of temperature.

The curves of the partial enthalpy of gelatinization for all the plasticizer contents studied are shown in Figure 3. This study presents the kinetics of the loss of ordered structure in starch for temperatures between 40 and $110^{\circ} \mathrm{C}$. An offset of the melting toward higher temperatures was observed when the Cc content increased; this was observed for the three starches and the flour.

The shapes of the curves shown in Figure 3 are rather different for $S_{P}$ and $S_{W}$ : the melting of the potato starch ordered zones was more abrupt than it was for the wheat starch and the wheat flour. These observations are in good agreement with the results of Waigh et al. on the two-stage destructuration of $S_{W}$ (crystallinity loss and helices destruction) [27]. Fannon, Hauber, and Bemiller showed that the $S_{P}$ granules appear smooth on the surface by scanning electron microscopy, whereas cereal grains such as $S_{W}$ have pores of about $100 \mathrm{~nm}$ at their surfaces, which are generated at the time of granule biosynthesis and cause a greater hydration sensitivity [28]. These observations may partly explain the differences in the plasticizer penetration into the granules for wheat starch and potato starch. 

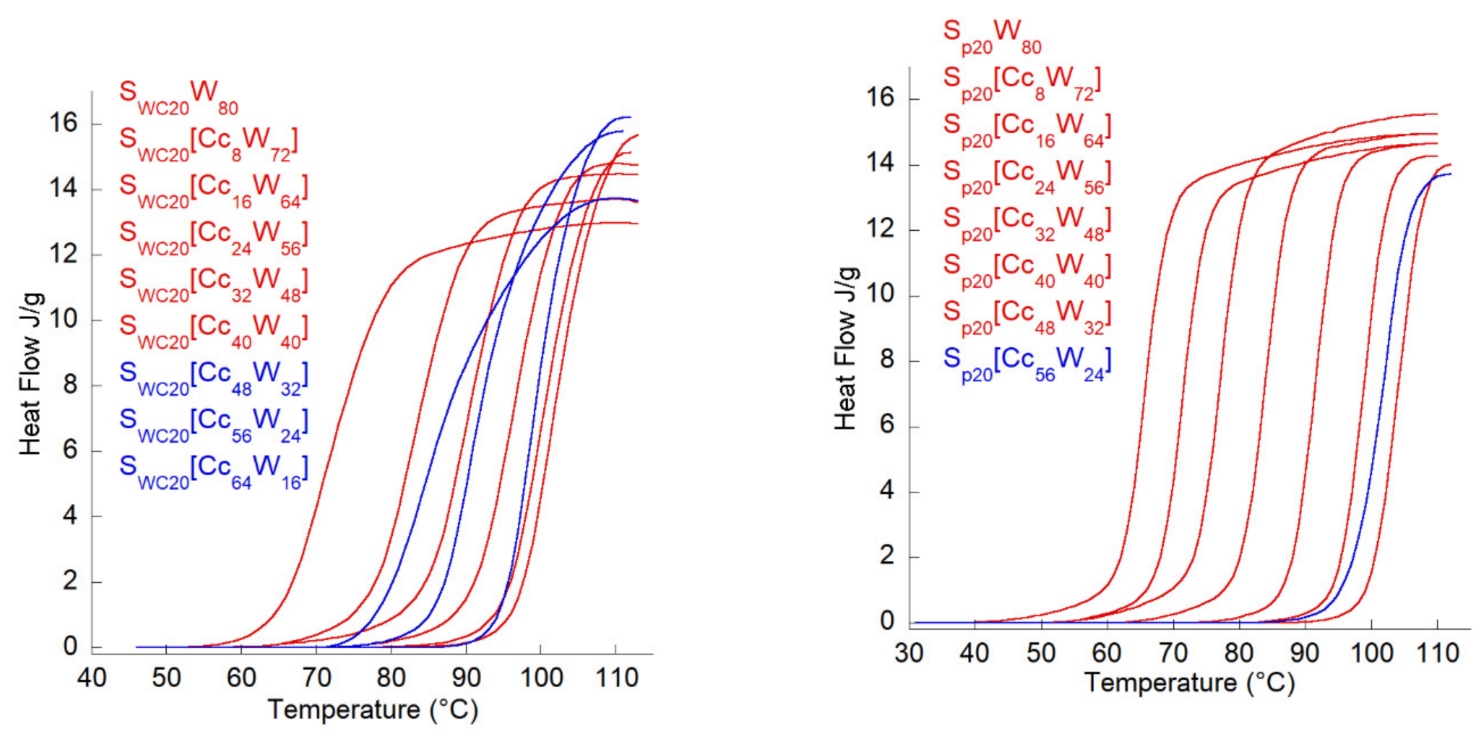

C
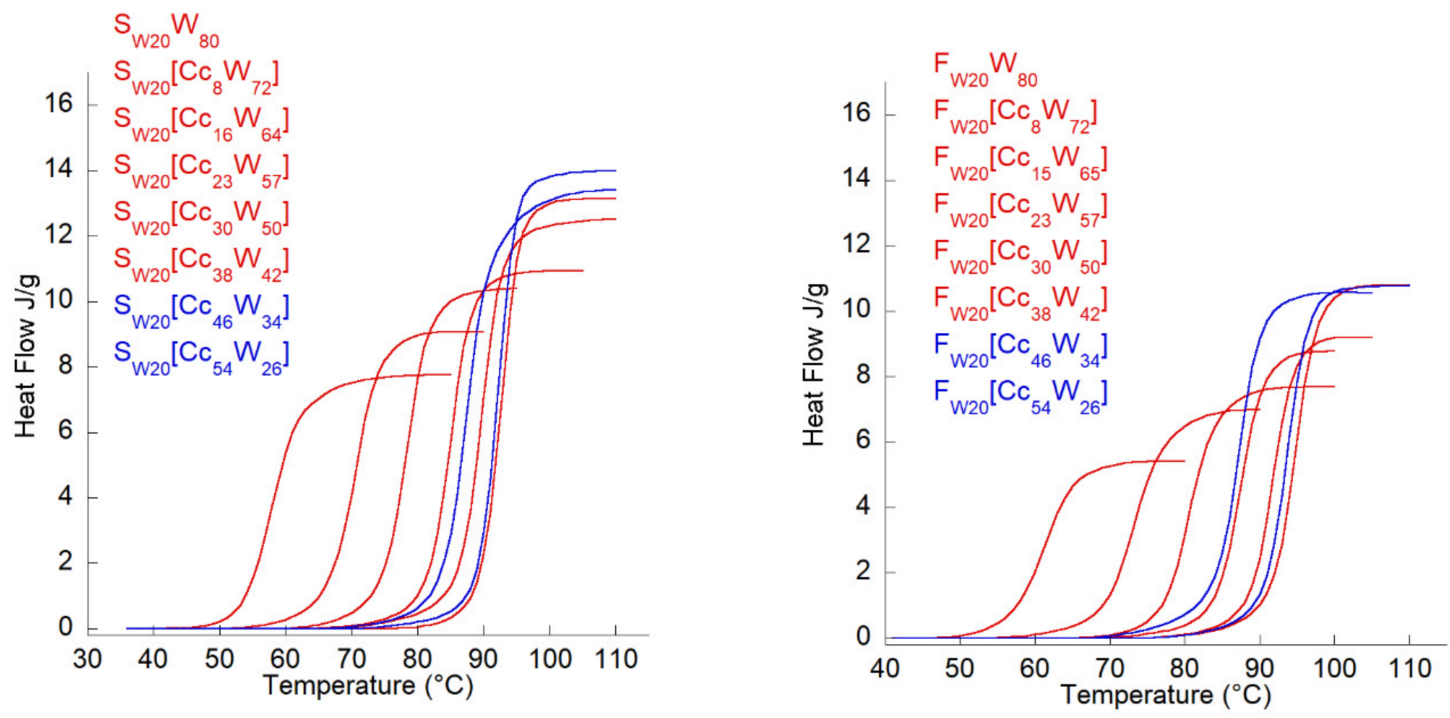

Figure 3. Curves of the partial enthalpy of gelatinization for all the plasticizer contents studied. (a) $\left[\mathrm{S}_{W C x} C c_{y}\right] W_{z} s y s t e m s$; (b) $\left[\mathrm{S}_{\mathrm{Px}} \mathrm{C}_{\mathrm{y}}\right] \mathrm{W}_{\mathrm{z}}$ system $;$; (c) $\left[\mathrm{S}_{\mathrm{Wx}} \mathrm{Cc}_{\mathrm{y}}\right] \mathrm{W}_{\mathrm{z}}$ systems; (d) $\left[\mathrm{F}_{\mathrm{Wx}} \mathrm{Cc}_{\mathrm{y}}\right] \mathrm{W}_{\mathrm{z}}$ systems.

For potato starch, the total gelatinization enthalpy $(\Delta \mathrm{H})$ in the presence of $C_{c}$ remained nearly constant at low concentrations of $\mathrm{Cc}$ but decreased slightly for higher concentrations. For wheat starch, the $\Delta \mathrm{H}$ increased significantly as the concentration of $\mathrm{Cc}$ increased, to a greater extent than that for the potato starch. This considerable increase in the total enthalpy of gelatinization of wheat starch at high Cc concentrations suggests a better organization of the ordered regions of starch in the presence of $\mathrm{Cc}$; on the other hand, when the concentration reached $40 \%$ for the Cc, the total enthalpy of the starch due to the fusion decreased perceptibly. The effect of high Cc concentrations on the gelatinization process 
was different for potato starch compared to waxy maize and wheat starch and wheat flour; it is assumed that this was due to the differences in the polymorphic structures.

The effect of $C_{C}$ on the gelatinization of $S_{P}$ is more pronounced in the first step of the gelatinization process (retardation of the loss of crystalline order), whereas for $\mathrm{S}_{\mathrm{W}}, \mathrm{F}_{\mathrm{W}}$, and $\mathrm{S}_{\mathrm{WC}}, \mathrm{Cc}$ also affects the second stage (delay in the loss of molecular order) and the overall enthalpy of the transition. These results are again opposite to those found in the literature for potato starch and wheat starch in the presence of high salt concentrations $(\mathrm{NaCl})$ [20].

\subsection{Impact of the Formulation on Starch Gelatinization}

As previously described, choline chloride in the absence of water is not considered as an ionic liquid. Therefore, it seemed interesting to observe the action of Cc on starch when $\mathrm{C}_{\mathrm{C}}$ is no longer acting as a plasticizer, but when it enters into the formulation as dry matter, $\mathrm{Cc}$ is placed directly in competition with water in front of starch. The relevant suspensions were formulated as follows: the starch (or flour) was mixed with the choline chloride (dry powder), and the water was added to the mixture. The obtained mixes were quoted using the following script: $\left[\mathrm{F}_{\mathrm{x}} \mathrm{Cc}_{\mathrm{y}}\right] \mathrm{W}_{\mathrm{z}}$. These mixtures were studied by $\mu \mathrm{DSC}$.

The temperatures and enthalpies of starch gelatinization did not vary with the formulation. However, there was a marked increase in the solubilization/rearrangement exotherm when the choline chloride was used as an ionic liquid (data not shown). This observation is explained by the fact that the solubilization of Cc before deposition on the starch allowed better penetration into the grain.

Another comparative study was carried out on the $\mathrm{F}_{\mathrm{W} 20} \mathrm{Cc}_{62} \mathrm{~W}_{18}$ system, with three different formulations (Figure 4):

- Formulation 1: the wheat flour was mixed with water before the introduction of choline chloride for $\left[\mathrm{F}_{\mathrm{W} 20} \mathrm{~W}_{18}\right] \mathrm{Cc}_{62}$.

- Formulation 2: choline chloride was mixed with water before being applied to the wheat flour for $\mathrm{F}_{\mathrm{W} 20}\left[\mathrm{Cc}_{62} \mathrm{~W}_{18}\right]$.

- Formulation 3: the wheat flour was mixed with choline chloride before the introduction of water for $\left[\mathrm{F}_{\mathrm{W} 20} \mathrm{Cc}_{62}\right] \mathrm{W}_{18}$.

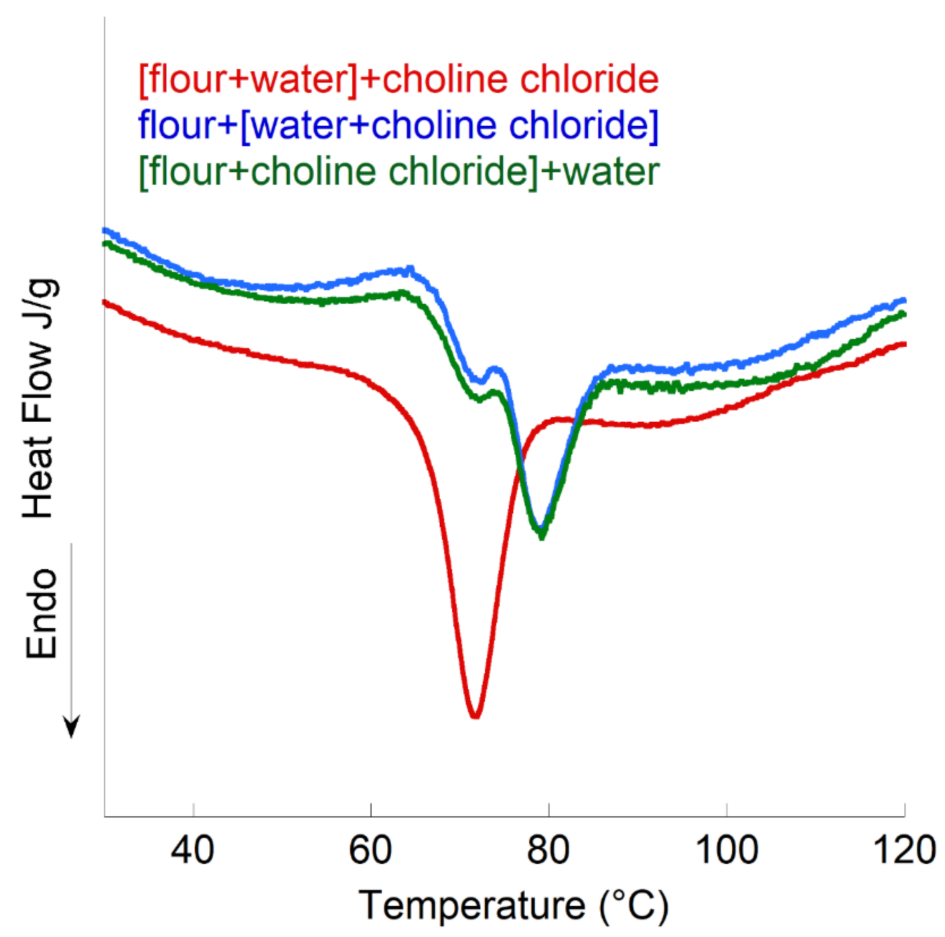

Figure 4. Comparative study of the thermograms of the systems $\left[\mathrm{F}_{\mathrm{W}_{20}} \mathrm{Cc}_{64}\right] \mathrm{W}_{16}, \mathrm{~F}_{\mathrm{W} 20}\left[\mathrm{Cc}_{64} \mathrm{~W}_{16}\right]$, and $\left[\mathrm{F}_{\mathrm{W} 20} \mathrm{~W}_{16}\right] \mathrm{Cc}_{64}$. 
The results clearly showed that when the water (in small quantities) is premixed with the flour, it becomes inaccessible to the choline chloride, causing gelatinization at $90{ }^{\circ} \mathrm{C}$ corresponding to a hydration of approximately $50 \%$, which agrees with the starting hydration (following formula).

$$
\begin{gathered}
\frac{\mathrm{F}_{20} \mathrm{~W}_{18}}{\square} \mathrm{CC}_{62} \\
\mathrm{~F}_{52} \mathrm{~W}_{48}
\end{gathered}
$$

There is also a broad endotherm of allotropic change in $\mathrm{Cc}$, suggesting that choline chloride has access to only a very small amount of water.

For the other two formulations, very similar results were obtained: namely, no change in the gelatinization temperature, a slightly more prominent exotherm for formulation 2 , and a small endotherm associated with the allotropic change in Cc.

In this part, we have shown that the order of incorporation of water into the system can influence the gelatinization of the studied starches. Indeed, if the water is added to the starch first, it binds enough to the starch to become unavailable for Cc. On the other hand, if the water is first added to the choline chloride, the latter is solubilized before entering as an ionic liquid in the starch.

\subsection{Evolution of the Structure of Different Starches in the Presence of Choline Chloride during Heating Kinetics}

To understand the phenomena underlying the exothermic transitions observed with the microcalorimeter, measurements by an XRD heating cell were made.

Two types of systems were compared with and without Cc. The starch/flour and water concentrations were the same in both systems. The X-ray diffraction spectra of each of the suspensions of waxy corn starch and potato starch are collated in Figure 5.

$\mathrm{S}_{\mathrm{WC}}, \mathrm{S}_{\mathrm{W}}$, and $\mathrm{F}_{\mathrm{W}}$ possess A-type polymorphic structures, and $\mathrm{S}_{\mathrm{P}}$ possesses a B-type polymorphic structure. In the diffraction spectra of the $\mathrm{S}_{\mathrm{W} 20} \mathrm{~W}_{24}$ (not shown), $\mathrm{F}_{\mathrm{W} 20} \mathrm{~W}_{24}$ (not shown), and $\mathrm{S}_{\mathrm{WC} 20} \mathrm{~W}_{24}$ systems, characteristic peaks of the A-type structure were identified. Spectra of the $\mathrm{S}_{\mathrm{P} 20} \mathrm{~W}_{24}$ system showed characteristic peaks of the B-type structure.

A notable difference is seen in the evolution of the spectra during heating between the samples without $C_{c}$ (Figure 5a,c) and those containing Cc (Figure 5b,d). Indeed, the peaks are more well defined in the systems without $\mathrm{Cc}_{\mathrm{c}}$, as with the addition of $\mathrm{Cc}$ at $20^{\circ} \mathrm{C}$. This confirms the previous conclusion: Cc causes a loss of crystalline order for all types of starch at room temperature. For the $\mathrm{S}_{\mathrm{P} 45} \mathrm{~W}_{55}$ system, the type-B structure disappears at a temperature of $90^{\circ} \mathrm{C}$. However, for type-A systems, the structure collapses near $90{ }^{\circ} \mathrm{C}$; this is consistent with Waigh's observations [29]. When Cc was added to the systems, a collapse of structure A or B was observed at much higher temperatures, which agrees with the results obtained by DSC.

For the $\mathrm{S}_{\mathrm{P} 20}\left[\mathrm{C}_{56} \mathrm{~W}_{24}\right]$ system, an increase in the peak intensity occurred at $5.6^{\circ}$ in $2 \Theta$ at a temperature of $60{ }^{\circ} \mathrm{C}$, followed by the onset of collapse at $100{ }^{\circ} \mathrm{C}$ and the total disappearance of the structure at $110^{\circ} \mathrm{C}$. This phenomenon corresponds to the appearance of the exotherm on the thermogram from the DSC study.

For systems $\mathrm{S}_{\mathrm{WC} 20}\left[\mathrm{C}_{56} \mathrm{~W}_{24}\right]$ and $\mathrm{S}_{\mathrm{W} 20}\left[\mathrm{C}_{56} \mathrm{~W}_{24}\right]$, the transition to an increase in crystallinity before melting is much less visible, and it is even absent for the $\mathrm{F}_{\mathrm{W} 20}\left[\mathrm{C}_{56} \mathrm{~W}_{24}\right]$ system. This explains the absence of the exotherm for the $\mathrm{F}_{\mathrm{W} 20}\left[\mathrm{C}_{56} \mathrm{~W}_{24}\right]$ system. In the literature, the exotherm is related to the solubilization of the starch in the plasticizer. However, during the X-ray diffraction study, we showed that the exotherm also corresponded to the increase in the intensity of the diffraction peaks and therefore to the increase in the crystallinity of the starch before its solubilization and then its melting. 

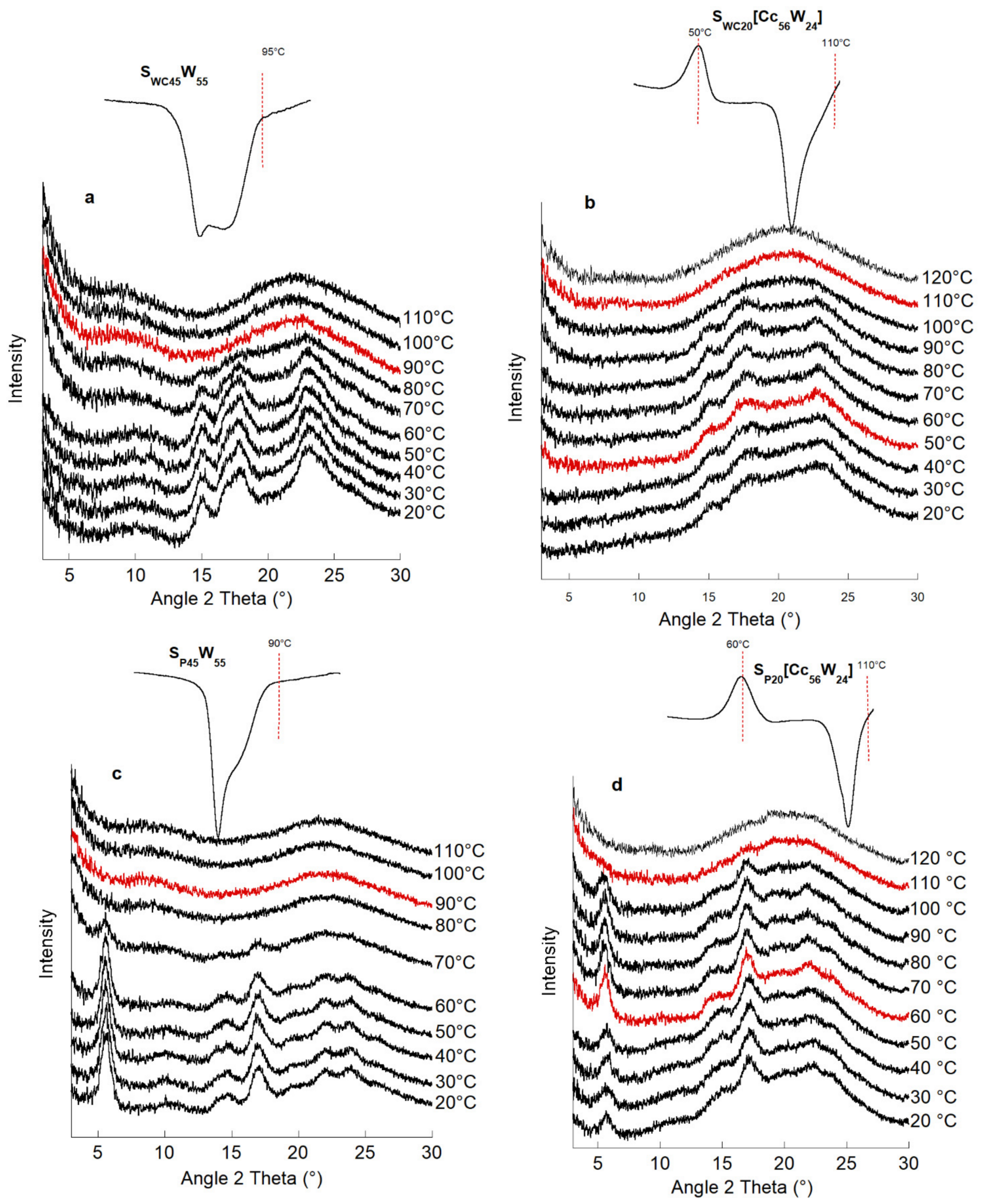

Figure 5. Evolution of the X-ray diffraction spectra during heating associated with the thermogram: waxy maize starch without $C_{c}$ : $S_{W C 45} W_{55}$ (a) and with $C_{c}$ : $S_{W C 20}\left[C_{C_{56}} W_{24}\right]\left(\right.$ b); potato starch without Cc: $S_{P 45} W_{55}$ (c) and with Cc: $\mathrm{S}_{\mathrm{P} 20}\left[\mathrm{CC}_{56} \mathrm{~W}_{24}\right](\mathbf{d})$.

To complete this work, a $\mu$ DSC study was conducted on the $\mathrm{S}_{\mathrm{P} 20}\left[\mathrm{C}_{56} \mathrm{~W}_{24}\right]$ system at low rates $\left(0.1^{\circ} \mathrm{C} / \mathrm{min}\right)$. Two peaks were clearly observed (Figure 6), indicating that more than one phenomenon is responsible for the exothermic transition observed. 


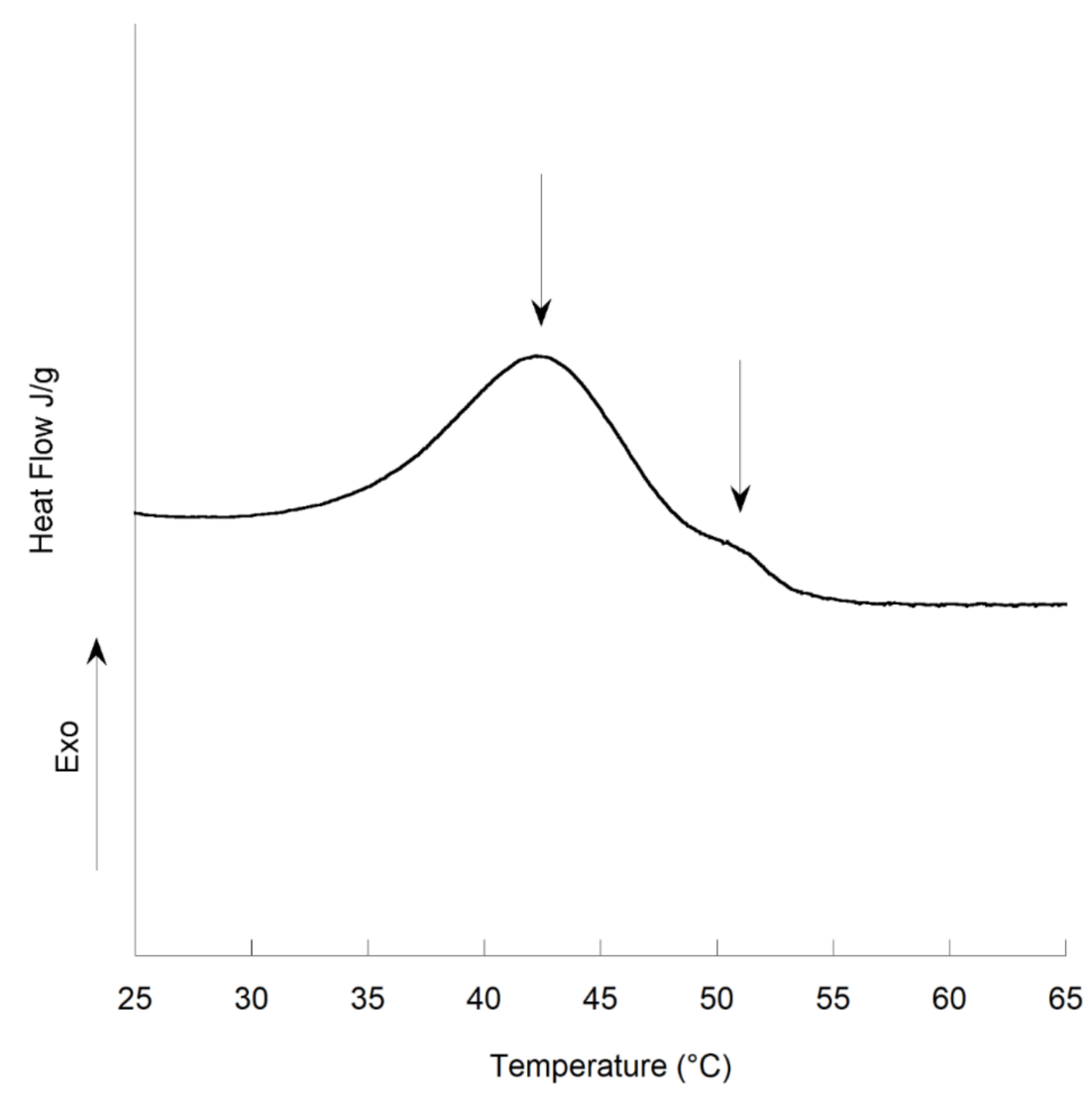

Figure 6. $\mu \mathrm{DSC}$ heating curves, $20-120^{\circ} \mathrm{C}$ at $0.1{ }^{\circ} \mathrm{C} / \mathrm{min}$, for $\mathrm{S}_{\mathrm{P} 20}\left[\mathrm{Cc}_{56} \mathrm{~W}_{24}\right]$.

\section{Conclusions}

The starch/water system shows a gelatinization accompanied or unaccompanied by a fusion, according to the water content of the matrix. The choline chloride/water system possesses the characteristics of an ionic liquid and exhibits an allotropic change at low water concentrations and solubilization for water contents greater than $30 \%$.

Choline chloride is an ionic compound, which, like $\mathrm{NaCl}$, has a "structure making" effect: that is, it increases the viscosity of the aqueous solution while decreasing the water fraction with high mobility. As a result, the gelatinization temperatures are displaced to higher temperatures. In contrast to the addition of $\mathrm{NaCl}$, the addition of choline chloride entails a significant increase in the gelatinization enthalpy, which suggests stabilization or better organization of the ordered regions of the starch in the presence of choline chloride.

An X-ray diffraction study in a heating cell demonstrated the crystalline rearrangement of the structure of the starch grain, which takes place simultaneously with the solubilization phenomenon of amylose.

Author Contributions: Conceptualization, A.L.-B. and P.L.-B.; methodology, D.C. and B.P.; formal analysis, D.C.; data curation, D.C., P.L.-B.; writing-original draft preparation, D.C., A.L.-B. et P.L.-B.; writing-review and editing, D.C., G.D. and P.L.-B.; supervision, P.L.-B.; project administration and funding acquisition, A.L.-B. All authors have read and agreed to the published version of the manuscript.

Funding: Co fundings by French Ministry of Agriculture (ONIRIS-ID for FOODS programme), by ONIRIS-GEPEA and by INRA-BIA.

Institutional Review Board Statement: Nothing to report.

Informed Consent Statement: Not applicable.

Data Availability Statement: Nothing to report. 
Acknowledgments: This project was supported by the French Ministry of Agriculture (ONIRIS-ID for FOODS programme), by ONIRIS-GEPEA and by INRA-BIA co fundings.

Conflicts of Interest: I certify that there is no conflict of interest.

\section{References}

1. Locke, K.W.; Fielding, S. Enhancement of salt intake by choline chloride. Physiol. Behav. 1994, 55, 1039. [CrossRef]

2. Yamaguchi, M.; Kainuma, K.; French, D. Electron microscopic observations of waxy maize starch. J. Ultrasructure Res. 1979, 69, 249. [CrossRef]

3. Oostergetel, G.T.; van Bruggen, F.J. On the Origin of a Low Angle Spacing in Starch. Starch Stärke 1989, 41, 331. [CrossRef]

4. Atwell, W.A.; Hood, L.F.; Lineback, D.R.; Marston, E.V.; Zobel, H.F. The terminology and methodology associated with basic starch phenomenon. Cereal Foods World 1988, 33, 306.

5. Lelievre, J. Starch gelatinization. J. Appl. Polym. Sci. 1974, 18, 293. [CrossRef]

6. Nikolic, M.A.L.; O'Sullivan, C.; Rounsefell, B.; Halley, P.J.; Truss, R.; Clarke, W.P. The anaerobic degradability of thermoplastic starch: Polyvinyl alcohol blends: Potential biodegradable food packaging materials. Bioresour. Technol. 2009, $100,1705$.

7. Liu, H.; Xie, F.; Yu, L.; Chen, L.; Li, L. Thermal processing of starch-based polymers. Prog. Polym. Sci. 2009, 34, 1348. [CrossRef]

8. Xie, F.; Halley, P.J.; Avérous, L. Rheology to understand and optimize processibility, structures and properties of starch polymeric materials. Prog. Polym. Sci. 2012, 37, 595. [CrossRef]

9. $\quad$ Biswas, A.; Shogren, R.L.; Stevenson, G.D.; Willett, J.L.; Bhowmik, P.K. Ionic liquids as solvents for biopolymers: Acylation of starch and zein protein. Carbohydr. Polym. 2006, 66, 546. [CrossRef]

10. Lappalainen, K.; Kärkkäinen, J.; Lajunen, M. Dissolution and depolymerization of barley starch in selected ionic liquids. Carbohydr. Polym. 2013, 93, 89. [CrossRef]

11. Liu, W.; Budtova, T. Dissolution of unmodified waxy starch in ionic liquid and solution rheological properties. Carbohydr. Polym. 2013, 93, 199. [CrossRef]

12. Mateyawa, S.; Xie, D.F.; Truss, R.W.; Halley, P.J.; Nicholson, T.M.; Shamshina, J.L.; Rogers, R.D.; Boehm, M.W.; McNally, T. Effect of the ionic liquid 1-ethyl-3-methylimidazolium acetate on the phase transition of starch: Dissolution or gelatinization? Carbohydr. Polym. 2013, 94, 520. [CrossRef]

13. Stevenson, D.G.; Biswas, A.; Jane, J.-L.; Inglett, G.E. Changes in structure and properties of starch of four botanical sources dispersed in the ionic liquid, 1-butyl-3-methylimidazolium chloride. Carbohydr. Polym. 2007, 67, 21. [CrossRef]

14. Zdanowicz, M.; Spychaj, T. Ionic liquids as starch plasticizers or solvents. Polim. Polym. 2011, 56, 861.

15. Decaen, P.; Rolland-Sabaté, A.; Guilois, S.; Jury, V.; Allanic, N.; Colomines, G.; Lourdin, D.; Leroy, E. Choline chloride vs choline ionic liquids for starch thermoplasticization. Carbohydr. Polym. 2017, 177, 424. [CrossRef]

16. Sciarini, L.S.; Rolland-Sabaté, A.; Guilois, S.; Decaen, P.; Leroy, E.; Le Bail, P. Understanding the destructuration of starch in water-ionic liquid mixtures. Green Chem. 2015, 17, 291. [CrossRef]

17. Le-Bail, P.; Houinsou-Houssou, B.; Kosta, M.; Pontoire, B.; Gore, E.; Le-Bail, A. Molecular encapsulation of linoleic and linolenic acids by amylose using hydrothermal and high-pressure treatments. Food Res. Int. 2015, 67, 223. [CrossRef]

18. Biliaderis, C.G.; Page, C.M.; Slade, L.; Sirett, R.R. Thermal behaviour of amylose-lipid complexes. Carbohydr. Polym. 1985, 47, 73

19. Kugimiya, M.; Donova, J.W.; Wong, R.Y. Phase Transitions of Amylose-Lipid Complexes in Starches: A Calorimetric Study. Starch Stärke 1980, 32, 265. [CrossRef]

20. Chiotelli, E.; Pilosio, G.; Le Meste, M. Effect of sodium chloride on the gelatinization of starch: A multimeasurement study. Biopolymers 2002, 63, 41. [CrossRef]

21. Chungcharoen, A.; Lund, D.B. Influence of Solutes and Water on Rice Starch Gelatinization. Cereal Chem. 1987, 64, 240.

22. Jane, J.-L. Mechanism of Starch Gelatinization in Neutral Salt Solutions. Starch Stärke 1993, 45, 161. [CrossRef]

23. Ahmad, F.B.; William, P.A. Effect of Salts on the Gelatinization and Rheological Properties of Sago Starch. J. Agric. Food Chem. 1999, 47, 3359. [CrossRef] [PubMed]

24. Ghani, M.B.A.; Che Man, Y.B.; Ali, A.B.; Hashim, D.B.M. Differential scanning calorimetry: Gelatinisation of sago starch in the presence of sucrose and sodium chloride. J. Sci. Food Agric. 1999, 79, 2001. [CrossRef]

25. Seetharaman, K.; Yao, N.; Rout, M.K. Role of Water in Pretzel Dough Development and Final Product Quality. Cereal Chem. 2004, 81, 336. [CrossRef]

26. Koganti, N.; Mitchell, J.R.; Ibbett, R.N.; Foster, T.J. Solvent Effects on Starch Dissolution and Gelatinization. Biomacromolecus 2011, 12, 2888. [CrossRef]

27. Waigh, T.A.; Kato, K.L.; Donald, A.M.; Gidley, M.J.; Clarke, C.J.; Riekel, C. Side-Chain Liquid-Crystalline Model for Starch. Starch Stärke 2000, 52, 450. [CrossRef]

28. Fannon, J.E.; Hauber, R.J.; BeMiller, J.N. Surface Pores of Starch Granules. Cereal Chem. 1992, 69, 284.

29. Waigh, T.A.; Gidley, M.J.; Komanshek, B.U.; Donald, A.M. The phase transformations in starch during gelatinisation: A liquid crystalline approach. Carbohydr. Polym. 2000, 328, 165. [CrossRef] 